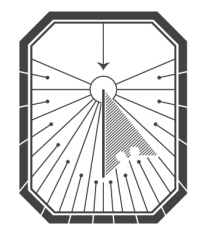

KYIV-MOHYLA

LAW \& POLITICS JOURNAL

KYIV-MOHYLA SCHOLARLY PEER-REVIEWED JOURNALS

\title{
Legal Complexities in the Service of Hybrid Warfare
}

Author(s): René Värk

Source: Kyiv-Mohyla Law and Politics Journal 6 (2020): 27-43

Published by: National University of Kyiv-Mohyla Academy

http://kmlpj.ukma.edu.ua/ 


\title{
Legal Complexities in the Service of Hybrid Warfare
}

\author{
René Värk \\ Associate Professor \\ University of Tartu, Estonia
}

\begin{abstract}
Hybrid warfare is about using military and non-military measures in a non-linear and complimentary fashion. Different means and methods are not necessarily effective separately, but it is their synergy that leads to the desired outcome. Law has also become a method of warfare. States exploit deliberately legal complexities to strengthen their own positions and to undermine the positions of their opponents. They may wish to keep the intensity of the employed measures below the threshold of the use or threat of force in order to argue that international law has not been breached and that the opponents may not exercise self-defense. States may equally try to avoid the application of the rules of warfare by claiming that the situation has not crossed the threshold of an armed conflict. Because the rules governing the resort to armed force and the conduct of hostilities were drafted for conventional warfare, the ambiguities, loopholes and thresholds in these rules provide opportunities, for better or for worse, in the era of modern warfare.
\end{abstract}

Key Words: hybrid warfare, lawfare, rules of warfare, use of force, Russia, Ukraine

\section{Introduction}

Warfare has evolved throughout history and, in turn, this has forced other domains, including law, to adapt to new realities. The so-called "hybrid warfare" is doing the same thing. Hybrid warfare is not a new phenomenon as the complementary deployment of military and non-military measures is relatively old, but it received renewed and substantive attention when Russia employed "new generation warfare" to annex Crimea in 2014.Russia resorted to a full spectrum of kinetic (e.g. regular and special forces) and non-kinetic measures (e. g. diplomatic and economic pressure, cyber and information operations) under a single unified command, and managed to achieve a centrally defined strategic political goal in a quick and rather bloodless way. The world and even Ukraine were surprised and failed to react adequately. Russia has continued hybrid warfare in Eastern Ukraine (although the activities have been considerably more kinetic in Donetsk and Luhansk) and has used some forms of hybrid warfare in Syria, Venezuela and Libya.

Contemporary warfare is a lot about perception. There are various and numerous national and international regulations about when states may use force, who and what 
are lawful targets, which means and methods of warfare are permissible, etc. States prefer to behave in accordance with their national and international legal obligations because it is generally beneficial and good for reputation. The latter creates a strong psychological effect, i. e. a wish to demonstrate to others that one is a law-abiding state. As a result, if a state is accused of violating international law, it does not admit it willingly and openly, but instead puts forward legal arguments which supposedly prove that its conduct is still lawful. For instance, states do not admit that they have committed an aggression, but usually claim that their action is self-defense or there is another reason why they are allowed to use force abroad. True, such arguments are not necessarily legally sound and accepted by other states.

Law is a method of hybrid warfare. The latter greatly politicizes the law and it is designed to exploit deliberately legal complexities, e. g. ambiguities, loopholes and thresholds. In order to fight hybrid warfare, we must be aware of such complexities and be able to use suitable counterarguments. As law is not a sole method of hybrid warfare, it is also not a sole answer, but one way among others to protect state's interests, and nowadays law plays a far more prominent role in warfare than ever before. Especially in the Western world which is therefore more receptive to the legal methods of hybrid warfare because the Western political, ethical and legal framework makes it both easier to intrude societies with such methods and more difficult for governmental authorities to fight such methods.

The article aims to clarify the essential characteristics of hybrid warfare and explain how select legal complexities in international law may become tools of hybrid warfare. A lot has been written about hybrid warfare lately but the majority of literature approaches hybrid warfare from non-legal perspectives. Despite the growing number of the sources on hybrid warfare, the concept remains vague and disagreements persist among authors, states and institutions. Although the use of hybrid warfare is not limited to Russia, the article focuses on the examples how Russia has understood and has employed hybrid warfare (hopefully, the temporal distance from the infamous events of 2014 offers additional perspectives).

\section{The Elusive Concept}

Before venturing to legal complexities, it is necessary to understand hybrid warfare. The aim is not to provide a comprehensive overview or s single definition, but to show that hybrid warfare is a vague concept, which is perceived differently depending on time, place and individuals or institutions. ${ }^{1}$ Hybrid warfare is inevitably an interdisciplinary concept which involves political, military, legal and other considerations. If hybrid warfare escapes a generally understood and accepted definition, then it is certainly not easy to determine its legal character. 
Most people had not heard of or thought about hybrid warfare before Russia annexed Crimea and started to interfere in Eastern Ukraine in 2014. Suddenly, hybrid warfare was high on the agenda and immediately people were debating whether hybrid warfare is something new or something old in a different form. To simplify, while certain ingredients of hybrid warfare are indeed old school, the combined package looks decidedly avant-garde. Already in 2005, James N. Mattis and Frank G. Hoffman predicted that the adversaries will skillfully merge different domains, means and methods of warfare, and such "unprecedented synthesis" becomes hybrid warfare. ${ }^{2}$ Two years later, Hoffman provided a more detailed vision of hybrid warfare which was widely accepted in military and academic circles, and serves as a starting-point discussions on hybrid warfare: "Hybrid Wars incorporate a range of different modes of warfare, including conventional capabilities, irregular tactics and formations, terrorist acts including indiscriminate violence and coercion, and criminal disorder." ${ }^{3} \mathrm{He}$ emphasized that even if such multimodal activities are conducted by separate units, all activities must be centrally directed and coordinate in order to achieve synergistic effects. What is also particularly important, Hoffman notes that both states and nonstate actors can conduct hybrid warfare. Indeed, hybrid warfare provides a rather accessible and affordable option for non-state actors, which allows the latter to choose the target, the time of attack, and the means and methods of attack.

In 2013, a year before the take-over of Crimea, General Valery Gerasimov, Chief of the General Staff of the Russian Federation, published an article ${ }^{4}$ that initially received moderate attention but later became the basis for the so-called Gerasimov doctrine ${ }^{5}$ (often used as a synonym for hybrid warfare). He recognized that "in the $21^{\text {st }}$ century we have seen a tendency toward blurring the lines between the states of war and peace" and "wars are no longer declared and, having begun, proceed according to an unfamiliar template". Gerasimov claimed that the very "rules of war" have changed and, perhaps most importantly, "the role of non-military means of achieving political and strategic goals has grown, and, in many cases, they have exceeded the power of force of weapons in their effectiveness." He foresaw the concealed, non-open use of force (paramilitary and civilian insurgent units) and emphasized the need to rely on asymmetric, indirect measures. Simultaneous and coordinated action is needed in both physical realm and

James N. Mattis and Frank G. Hoffman, "Future Warfare: The Rise of Hybrid Wars," Proceedings Magazine 131 (2005): 19.

3 Frank G. Hoffman, Conflict in the 21st Century: The Rise of Hybrid Warfare (Arlington: Potomac Institute for Policy Studies, 2007), 14.

Valerij Gerasimov, “Cennost nauki v predvidenii: Novye vyzovy trebuyut pereosmyslit formy i sposoby vedeniya boevyh dejstvij [The Validity of Science is in Prediction: New Challenges Require Rethinking of Forms and Methods of Armed Activities Conduction]," Voenno-promyshlennyj kurer, 27 fevralya 2013, accessed March 31, 2020, http://www.vpk-news.ru/ articles/14632. 
information space in order to target and to influence the whole society. Gerasimov did not rule out conventional armed force but "the open use of forces (often under the guise of peacekeeping and crisis regulation) is resorted to only at a certain stage, primarily for the achievement of final success in the conflict". His new generation warfare is nonlinear, full spectrum and, hopefully, militarily low-intensity warfare.

In 2014, Russia put these ideas to test in Crimea and suddenly Gerasimov's article seemed like a prediction of future from 2013. Did the world witness something novel? As mentioned above, hybrid warfare is not a new phenomenon, but what was innovative was the highly integrated design and implementation of the whole campaign. Also, Russia took skillfully advantage of the ambiguities, loopholes and thresholds in law to claim that its conduct was lawful and to discredit Ukraine and its supporters, e. g. the NATO, the European Union and other likeminded states. For example, it was said that the incorporation of Crimea was based on the legitimate exercise of self-determination 6 ; the militias which were well-equipped, but lacked insignia ("little green men") were voluntary locals who had no links to Russia; ${ }^{7}$ the sanctions against Russia were unlawful because they were not adopted by the Security Council (where Russia has a veto-right). ${ }^{8}$ These limited examples show that law is a method of hybrid warfare.

Retrospectively, it is worth noting that Russia tested some elements of hybrid warfare already during the Georgian-Russian conflict in 2008. Russia used the "peacekeeping forces" present in South Ossetia to hide the build-up of troops and weapons. Russia shaped the narrative with the help of Russian journalists who were specially brought to South Ossetia. Russia had for some time issued passports to the population of South Ossetia and claimed that it had to protect its nationals from the threats posed by Georgia. These are merely a few examples. However, the examination of that conflict is beyond the scope of this article.

It is worth mentioning that China has developed its own form of hybrid warfare, ${ }^{9}$ and has identified and learnt lessons also from Russia's experience. In 2003, the Central Military Commission approved the concept of "three warfares" which include media,

6 Ministerstvo inostrannyh del Rossijskoj Federacii, "Pravovye obosnovaniya pozicii Rossii po Krymu i Ukraine [Legal Grounds of Russia's Position on Crimea and Ukraine]," 27 oktyabrya 2014, accessed March 31, 2020, http://russische-botschaft.ru/wp-content/uploads/2014/10/ Krym-pravovye-osnovy.doc.

7 Alberto Riva, "Russia's Use of Unmarked Troops in Simferopol, Crimea: Shady, But Not Illegal," International Business Times, March 4, 2014, accessed March 31, 2020, https://www.ibtimes. com/russias-use-unmarked-troops-simferopol-crimea-shady-not-illegal-1559425; Ewen MacAskill, “Russian troops removing ID markings 'gross violation," The Guardian, March 6, 2014, accessed March 31, 2020, https://www.theguardian.com/news/defence-and-securityblog/2014/mar/o6/ukraine-gross-violation-russian-troops.

8 John J. A. Burke, "Economic Sanctions against the Russian Federation Are Illegal under Public International Law," Russian Law Journal 3 (2015): 126.

9 Sangkuk Lee, “China's 'Three Warfares': Origins, Applications, and Organizations,” Journal of Strategic Studies37 (2014): 198. 
psychological and legal operations, which are used in combination as a surrogate for conventional conflict. Legal operations use international and national law to pursue the interests of China and to mitigate possible political repercussions of China's military action. ${ }^{10}$ Therefore, hybrid warfare is not something that should be associated only with Russia and it is not a concern only for states which are in Russia's self-proclaimed sphere of interest. Hybrid warfare can take place anywhere as long as the conditions are favorable for such campaigns.

The NATO and the European Union have also addressed hybridity, but they have combined "hybrid warfare" with "hybrid threats" — while the former focuses on violent activities, the latter covers a broader selection of activities across the entire spectrum of crisis or conflict. ${ }^{11}$ It sends a signal that hybridity is not a concern solely for ministries of defense and armed forces but also for ministries of foreign affairs and of other fields where hybridity may be employed.

The NATO Summit in 2014 was overshadowed by Russia's on-going hybrid warfare in Eastern Ukraine and therefore it is not surprising that the Wales Summit Declaration addressed "hybrid warfare threats, where a wide range of overt and covert military, paramilitary, and civilian measures are employed in a highly integrated design." 12 This concise sentence reflects the ideas of Gerasimov and the conduct of Russia in Crimea and Eastern Ukraine. It is worth mentioning that the declaration recognized one vital aspect which distinguishes the current hybrid warfare from the rather oldschool complementary deployment of military and non-military measures - the highly integrated design and implementation of the whole campaign. The subsequent summit declarations took a broader approach to hybrid warfare threats, and indicated that "the Alliance and Allies will be prepared to counter hybrid warfare as part of collective defence [and] the Council could decide to invoke Article 5 of the Washington Treaty"13 and, ever more clearly, "in cases of hybrid warfare, the Council could decide to invoke Article 5 of the Washington Treaty, as in the case of armed attack."14 Hybrid threats have now found their way to the capstone NATO doctrine which explains the

10 See Stefan Halper, "China: The Three Warfares," Report to the Office of the Secretary of Defense (May 2013): 46-70 for detailed discussion of legal operations.

11 Frank G. Hoffman, "On Not-So-New Warfare: Political Warfare vs Hybrid Threats," War on the Rocks, July 28, 2014, accessed March 31, 2020, https://warontherocks.com/2014/o7/on-not-sonew-warfare-political-warfare-vs-hybrid-threats/. North Atlantic Treaty Organization, "Wales Summit Declaration," September 5, 2014: paragraph 13, accessed March 31, 2020, http://www.nato.int/cps/en/natohq/official_ texts_112964.htm.

13 North Atlantic Treaty Organization, "Warsaw Summit Declaration," July 9, 2016: paragraph 72, accessed March 31, 2020, https://www.nato.int/cps/en/natohq/official_texts_133169.htm.

14 North Atlantic Treaty Organization, "Brussels Summit Declaration," July 11, 2018: paragraph 21, accessed March 31, 2020, https://www.nato.int/cps/en/natohq/official_texts_133169.htm. 
strategic context for joint operations, and focuses on the underlying philosophy and fundamentals of joint operations. ${ }^{15}$

The European Union echoes the sentiment of some actors that it is futile to provide a definition of hybrid threats and we should watch out for evolving forms of hybrid threats. Hence, "while definitions of hybrid threats vary and need to remain flexible to respond to their evolving nature, the concept aims to capture the mixture of coercive and subversive activity, conventional and unconventional methods (i.e. diplomatic, military, economic, technological), which can be used in a coordinated manner by state or non-state actors to achieve specific objectives while remaining below the threshold of formally declared warfare." ${ }^{6}$ The last element ("below the threshold of formally declared warfare") is strange for two reasons. First, does it mean that there is no place for hybridity once the situation has crossed the threshold of a conventional conflict? One characteristic of hybrid warfare is parallel non-linear use of conventional, irregular and asymmetric means and methods of warfare. Second, formal declarations of war have long become obsolete and are legally irrelevant under current international law. ${ }^{17}$

Some states have incorporated hybrid warfare or threats to their military doctrine. The United States Army Doctrine Reference Publication gives an interesting explanation because it admits hybrid threats can take advantage of international law. It defines a hybrid threat as "the diverse and dynamic combination of regular forces, irregular forces, terrorist forces, or criminal elements unified to achieve mutually benefitting threat effects." 18 The document also elaborates that hybrid threats capture "the complexity of operational environments, the multiplicity of actors involved, and the blurring between traditional elements of conflict" and combine "traditional forces governed by law, military tradition, and custom with unregulated forces that act without constraints on the use of violence". This reflects again the concern that it is difficult to legally characterize the conflict and it is not always certain which (or, as some say, if any) rules apply.

15 North Atlantic Treaty Organization, Allied Joint Doctrine, AJP-o1, Edition E Version 1

(February 2017): paragraph 2.19.e ("Hybrid threats occur where conventional, irregular and asymmetric threats are combined in the same time and space. Conflict could involve a range of transnational, state, group and individual participants operating globally and locally. Some conflicts may involve concurrent inter-communal violence, terrorism, cyberspace attacks, insurgency, pervasive criminality and widespread disorder. Adversaries may also choose a longterm strategy to avoid defeat rather than seeking victory, to try to outlast NATO's will and determination. Countering such hybrid threats may require a broader approach, employing integrated capabilities some of which may be unconventional in nature.").

16 European Commission, Joint Framework on Countering Hybrid Threats: A European Union Response, April 6, 2016, JOIN (2016) 18 final: 2.

17 See René Värk, "Declared and Undeclared Wars," Journal on Baltic Security3, no. 1 (2017): 25 for the purpose and current legal meaning of a declaration of war.

18 United States Army Doctrine Reference Publication 3-0, Operations, October 6, 2017: paragraphs $1-15$. 
In all fairness, there are authors who are critical about the concept of hybrid warfare for various reasons, e. g. it is a publicity cliché, not a scientific term; ${ }^{19}$ there is nothing novel; ${ }^{20}$ it can be used to describe anything unconventional; ${ }^{21}$ hybrid warfare is too much linked to Russia and it was successful in Ukraine due to ideal circumstances. ${ }^{22}$ Such critic deserves attention so that we do not get enchanted with the belief that one concept can explain everything unusual.

\section{The Legal Challenges}

Numerous opinions have been expressed about the concept of hybrid warfare and what are the political and military implications of hybrid warfare. Legal discussions have been modest and fragmented in comparison. Some authors find that there is nothing about hybrid warfare and therefore it does not pose specific legal issues. ${ }^{23}$ Well, they are partially correct because in case of hybrid warfare we face similar challenges as in case of conventional warfare, e. g. respect for sovereignty, prohibition to encourage and support separatism, opportunistic interpretation of international law, use of proxies and plausible deniability of attribution. However, while these challenges are consequential to conventional warfare, hybrid warfare exists and relies partially on the ambiguities, loopholes and thresholds in international law. That is new. As mentioned before, law has been weaponized, and has become a strategic enabler or force multiplier. Again, the continuing conflict in Ukraine demonstrates how Russia has cleverly exposed and exploited the international legal order's structural weaknesses in its favor.

Traditional international law is based on several binaries such as the distinction between peace and war. The famous treatises of Hugo Grotius, On the Law of War and Peace (1625), was based on the assumption that we are either in the state of peace or war and respective rules apply. This binary has largely continued to the present moment ${ }^{24}$ and has been solidified in numerous rules and concepts of international law. It should be easy - once we know whether we are in a state of peace or war, we know what legal framework becomes applicable internationally and nationally. What if the adversary creates a situation where we are confused whether it is peace, crisis or

Petr Topychkanov, “"Hybrid War” — a Scholarly Term or a Propaganda Cliché?” Carnegie

Endowment for International Peace, July 17, 2015, accessed March 31, 2020, https://

carnegieendowment.org/2015/o7/17/hybrid-war-scholarly-term-or-propaganda-clich\%C3\%A9.

Michael Kofman, and Matthew Rojansky, “A Closer look at Russia's “Hybrid War,"” Kennan

Cable, no. 7 (2015).

21 Samuel Charap, “The Ghost of Hybrid War," Survival 57, no. 6 (2017): 51.

22 Andrew Monaghan, “The 'War' in Russia's 'Hybrid Warfare," Parameters 45, no. 4 (2015): 65.

23 For example, Benjamin Wittes, "What Is Hybrid Conflict?" Lawfare, September 11, 2015, accessed March 31, 2020, https://www.lawfareblog.com/what-hybrid-conflict.

See Georg Schwarzenberger, "Jus Pacis Ac Belli? Prolegomena to a Sociology of International Law," American Journal of International Law 37 (1943): 46o for a classical examination of the peace vs war approach in international legal order. 
war? When does one state of affairs begin or transform to another? Which rules apply? Which institution should deal with the situation, e. g. law enforcement or armed forces? These concerns were echoed by Michael Fallon, United Kingdom Secretary of Defence, when he discussed the need to further internationalize defense and security sector, and told that we have to think about "the way we respond collectively to new threats such as hybrid warfare - where aggressors use proxies and cyber-attack to blur the lines between what is, and what is not, considered an act of war." ${ }^{25}$ This is a challenge for general international law, but especially for international humanitarian law, which has traditionally concentrated on more tangible and conventional military warfare, and whose rules assume that we can distinguish between states of peace and war.

\subsection{Has There Been a "Use of Force" or an "Armed Attack"?}

After the Second World War, the international community decided to restrict the right of states to use military measures in international relations. The previous legal regulation had been inadequate, and several states (e. g. Japan, Italy, Germany) managed to evade the prohibition to use war and invaded other states. ${ }^{26}$ The United Nations Charter (1945) provides that "all Members shall refrain in their international relations from the threat or use of force against the territorial integrity or political independence of any state, or in any other manner inconsistent with the Purposes of the United Nations." ${ }^{27}$ This is a fundamental rule in modern international $\operatorname{law}^{28}$ and the international community reacts very strongly to its breaches.

But what if a state could achieve its strategic goals without using force? As mentioned above, Gerasimov believed that "the role of non-military means of achieving political and strategic goals has grown, and, in many cases, they have exceeded the power of force of weapons in their effectiveness." ${ }^{29}$ If the state manages to keep the intensity of the employed measures below the threshold of the use or threat of force,

25 United Kingdom Government, "Defence Secretary's speech to RUSI on the SDSR 2015,"

September 22, 2015, accessed March 31, 2020, https://www.gov.uk/government/speeches/

defence-secretarys-speech-to-rusi-on-the-sdsr-2015.

Ian Brownlie, International Law and the Use of Force by States (Oxford: Clarendon Press, 1963), 74-80.

Charter of the United Nations, San Francisco, June 6, 1945, entry into force October 24, 1945, 1 UNTS xvi: Article 2(4). The provision does not clarify what kind of "force" is prohibited but its travaux préparatoires and subsequent interpretations suggest that states had in mind "armed force." Yoram Dinstein, War, Aggression and Self-Defence $\left(5^{\text {th }}\right.$ edn, Cambridge University Press, 2011), 88.

The International Court of Justice has regarded the prohibition of the use of force as "a conspicuous example of a rule of international law having the character of ius cogens". International Court of Justice, Legal Consequences of the Construction of a Wall in the Occupied Palestinian Territory, Advisory Opinion, ICJ Reports (2004) 136: paragraph 190. 
it is possible to argue that international law has not been breached. Sure, a state can successfully use non-military measures instead of military measures when the circumstances are favorable.

How did the rules on the use of force apply in the case of Crimea? It would be a rational conclusion that force was used covertly in order to annex a part of another state's territory. However, the Russian President Vladimir Putin gave a speech where he stated that it is strange to talk about intervention or aggression because not a single shot was fired and there were no casualties. ${ }^{30}$ Russia had not breached international law because there was no use of force. If the Russian armed forces had done something, ${ }^{31}$ they supported the population of Crimea in their exercise of the right of self-determination under international law.

If necessary, states may rather freely use non-military measures (e.g. diplomatic and economic sanction) to protect their rights and interests. However, military measures may be used under the United Nations Charter for self-defense or based on a mandate from the Security Council. ${ }^{32}$ The latter option is unlikely if the situation concerns a permanent member of the Security Council (China, France, Russia, the United Kingdom and the United States). Self-defense need no permission from the Security Council but requires an "armed attack" against a state. International law does not define what constitutes an "armed attack" and ultimately it is a political decision. ${ }^{33}$ State and court practice shows that not every use of force validates the exercise of selfdefense, i. e. the threshold for an armed attack is higher than for the use of force. The International Court of Justice has emphasized that it is "necessary to distinguish the most grave forms of the use of force (those constituting an armed attack) from other less grave forms" ${ }^{34}$ and only the former cases allow self-defense. ${ }^{35}$ Therefore, a shot across the border is a use of force, but should it initiate a military reaction or should a state limit itself to a non-military reaction (i. e. the state should have "thick skin" for such incidents)? There is no single authoritative answer to the question from which moment the exercise of self-defense becomes definitively lawful.

Vladimir Putin, "Address by President of the Russian Federation," accessed March 31, 2020, http://en.kremlin.ru/events/president/news/206o3.

Vladimir Putin admitted that the Russian armed forces were in Crimea on April 17, 2014. Vladimir Putin, "Direct Line with Vladimir Putin," accessed March 31, 2020, http://en.kremlin. ru/events/president/news/20796. Charter of the United Nations, respectively Articles $5^{1}$ and 42.

33 See Tom Ruys, "Armed attack" and Article 51 of the UN Charter: Evolutions in Customary Law and Practice (Cambridge: Cambridge University Press, 2010) for a thorough analysis on what constitutes an "armed attack" for the purposes of self-defence. International Court of Justice, Military and Paramilitary Activities in and against Nicaragua (Nicaragua v. United States), Merits, ICJ Reports (1986) 14: paragraph 191. 
Article 5-the central provision of the North Atlantic Treaty ${ }^{36}$ - is based on Article 51 of the United Nations Charter and depends similarly on the occurrence of an armed attack. Originally, Article 5 was meant to counter a traditional inter-state attack, but when the provision was used for the first time in September 2001, it happened in a situation where a non-state actor attacked a state (the September 11, 2001 attacks against the United States). ${ }^{37}$ The NATO stretched Article 5 further in the NATO summit declarations of 2016 and 2018, which now foresee a possibility that a hybrid attack may constitute an armed attack and lead possibly to use of force as a response. ${ }^{38}$ This is legally sound if a hybrid attack is comparable in scale and effect to an armed attack but in other situations, the NATO should address the situation under Article 4 using non-military measures.

Hybrid warfare aims to take advantage of the thresholds in international law and this is one such threshold. If a state keeps low intensity (e. g. avoids visible cross-border clashes, resorts to multiple and seemingly sporadic strikes of minimal violence), it makes it difficult for the target state to claim that an armed attack has occurred and it may exercise self-defense. The catch is that even though a state has a unilateral right to assess whether the preconditions of self-defense are met, sooner or later it has to justify its decision to exercise self-defense before the international community. If the state fails to convince others, the state faces a possible accusation that it has instead committed an act of aggression.

Interestingly, Japan employed similar rhetoric already in 1931. Three years earlier, states had declared the Kellogg-Briand Pact that they "condemn recourse to war for the solution of international controversies, and renounce it, as an instrument of national policy in their relations with one another." ${ }^{39}$ So, war had been outlawed. In September 1931, Japan began the invasion of Manchuria, a region of China. What followed was years of hostilities but neither China nor Japan declared war, break off diplomatic relations or request third States to observe neutrality (however, China did declare war on Japan in the context of the Second World War in December 1941). Japan claimed that the rules of warfare did not apply because such rules apply only during war which did not exist. Later, Japan disputed that it could not commit war crimes because the latter are violations of the rules of warfare. The League of Nations accepted that there had been no resort to war by Japan or China and therefore, no violation of the obligation to exhaust the methods of peaceful settlement of dispute before going to war. How did Japan and later other states qualify their "not war" situations? They showed some

36 North Atlantic Treaty, Washington, April 4, 1949, entry into force August 24, 1949, 34 UNTS 243.

37 North Atlantic Treaty Organization, "Statement by the North Atlantic Council," September 12, 2001, accessed March 31, 2020, https://www.nato.int/docu/pr/2001/po1-124e.htm.

38 North Atlantic Treaty Organization, "Warsaw Summit Declaration," paragraph 72; North Atlantic Treaty Organization, "Brussels Summit Declaration," paragraph 21.

39 Treaty Providing for the Renunciation of War as an Instrument of National Policy, Paris, August 27, 1928, entry into force July 24, 1929, 94 LNTS 57 [usually knows as the Kellogg-Briand Pact]: Article I. 
imagination, e. g. Japan called its invasion in Manchuria an "incident" and in 1936, when Italy annexed Abyssinia, Mussolini described the undertaking an "expedition." 40

\subsection{Is there an "Armed Conflict"?}

Both national and international law contain various and numerous rules on the conduct of hostilities. Some rules are common for all possible conflicts, but others are designed for a specific type of conflict. Although violent situations may seem more or less the same (e. g. people are wounded and killed, property is damaged and destroyed, people are forced to leave their homes or even countries, societal and governmental organization is not functioning normally), they are legally different. Once a conflict breaks out, it is necessary to determine the legal character of the particular conflict in order to establish which legal framework is applicable.

International humanitarian law is branch of international law specifically designed to regulate the conduct of hostilities in armed conflicts. The latter are broader than wars (e. g. a declaration of war or a recognition of the state of war is not necessary) and were include intentionally to expand the application of international humanitarian law. ${ }^{41}$ The aim was to make it impossible for the states to avoid their obligation under international humanitarian law by denying the existence of a formal war (as Japan did in the case of Manchuria discussed above). What matters are the objective facts, e. g. if fighting takes place, then international humanitarian law becomes applicable regardless of how states may describe the situation.

Depending on the prevailing circumstances, the conflicts are either international armed conflicts or non-international armed conflicts. ${ }^{42}$ However, it is not easy to determine the legal character of a particular conflict. First, law does not provide a convenient tool (like a checklist) for the task. Still, we can turn to state and court practice, which give useful guidelines in terms of how and what to assess in order to make a determination. Foremost, we consider the intensity of the conflict and who are the parties to the conflict. Second, despite these guidelines, there is no single institution to make an explicit and authoritative determination.

The term hybrid warfare suggests that it happens within some kind of conflict and involves some degree of hostilities. Therefore, it is a valid question whether international humanitarian law regulates the activities of hybrid warfare. Why it matters? When international humanitarian law becomes applicable, other peacetime regulations may

40 Nico Schrijver, "The Ban on the Use of Force in the UN Charter," in The Oxford Handbook of the Use of Force in International Law, ed. Marc Weller (Oxford: Oxford University Press, 2015): 468-69.

International Committee of the Red Cross, Commentary on the First Geneva Convention: Convention (I) for the Amelioration of the Condition of the Wounded and Sick in Armed Forces in the Field ( $2^{\text {nd }}$ edn, Cambridge: Cambridge University Press, 2016): paragraphs 203-16.

42 Sylvain Vité, "Typology of Armed Conflicts in International Humanitarian Law: Legal Concepts and Actual Situations," International Review of the Red Cross 91, no. 873 (2009): 69. 
recede in favor of international humanitarian law (e. g. it is possible to derogate from human rights), which functions as lex specialis. ${ }^{43}$ For example, adversary combatants and civilians who take direct part in hostilities become legitimate targets. ${ }^{44}$ If certain persons engage in hybrid warfare, it is important to know if we may lawfully attack them.

The nature of hybrid warfare makes it even more difficult to decide, first, whether hybrid warfare qualifies as an armed conflict, and, then, whether it is an international or non-international armed conflict. The mentioned guidelines have developed in a more conventional kinetic military context, but hybrid warfare a lot about unconventional, non-kinetic and non-military means and methods. Moreover, those who plan and conduct hybrid warfare are well aware of these guidelines and try to avoid crossing, as far as possible, the thresholds of different types of conflict.

The Geneva Conventions (1949), ${ }^{45}$ which introduced the legal concept of armed conflict, their subsequent additional protocols $(1977)^{46}$ do not provide a definition of armed conflict even though the application of all these treaties depends on the existence of armed conflicts. The usual reference point for defining armed conflicts is the Tadic case, where the International Criminal Tribunal for the former Yugoslavia (ICTY) established that "an armed conflict exists whenever there is a resort to armed force between States or protracted armed violence between governmental authorities and organized armed groups or between such groups within a State." 47

The ICTY managed to include both international and non-international armed conflict into one sentence. First, an international armed conflict exists whenever there is "a resort to armed force between States." The International Committee of the Red

43 International Court of Justice, Legality of the Threat or Use of Nuclear Weapons, Advisory

Opinion, ICJ Reports (1996) 226: paragraph 25.

Civilians who take direct part in hostilities do not become combatants but lose their civilian protection "for such time as they take a direct part in hostilities". Protocol Additional (I) to the Geneva Conventions, relating to the Protection of Victims of International Armed Conflicts,

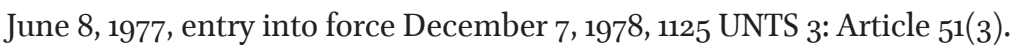

Geneva Convention for the Amelioration of the Condition of the Wounded and Sick in Armed Forces in the Field, August 12, 1949, entry into force October 21, 1950, 75 UNTS 31: Articles 2-3; Geneva Convention for the Amelioration of the Condition of Wounded, Sick and Shipwrecked Members of Armed Forces at Sea, August 12, 1949, entry into force October 21, 1950, 75 UNTS 85: Articles 2-3; Geneva Convention Relative to the Treatment of Prisoners of War, August 12, 1949, entry into force October 21, 1950, 75 UNTS 135: Articles 2-3; Geneva Convention Relative to the Protection of Civilian Persons in Time of War, August 12, 1949, entry into force October 21, 1950, 75 UNTS 287: Articles 2-3.

46 Protocol Additional (I) to the Geneva Conventions, Article 1; Protocol Additional (II) to the Geneva Conventions, relating to the Protection of Victims of Non-International Armed Conflicts, June 8, 1977, entry into force December 7, 1978, 1125 UNTS 6og: Article 1. 
Cross (ICRC) has explained in its commentaries to the Geneva Conventions that "any difference arising between two States and leading to the intervention of armed forces is an armed conflict within the meaning of Article 2, even if one of the Parties denies the existence of a state of war" and, famously, "it makes no difference how long the conflict lasts, or how much slaughter takes place." 48 Second, a non-international armed conflict exists whenever there is "a resort to armed force between States protracted armed violence between governmental authorities and organized armed groups or between such groups within a State".

These limited examples demonstrate that the definitions of armed conflict include violence as a central element. Therefore, unless the means and methods of hybrid warfare are not combined with the kinetic means and methods of warfare, it is difficult to see how solely non-kinetic hybrid warfare could be characterized as an armed conflict. It means also that international humanitarian law does not govern the employment of hybrid warfare; instead, it is peacetime legal framework (including human rights law) that applies in such situations. Nevertheless, the situations of hybrid warfare are unusual and it is likely that states want to resort to more forceful measures than normally available in peacetime by emphasizing "military necessity" and "with the idea of military necessity becoming paramount, a concomitant deterioration of legal incentives to act humanly is inevitable." 49 In other words, the application of more humane rules to not necessarily lead to more humane results.

\section{Conclusion}

The concept of hybrid warfare that rose to prominence in 2014 has been treated with mixed feelings. Some view the concept as a useful tool to understand recent confrontation, especially with Russia, while others consider the concept useless, over simplifying or nothing novel. The concept is interdisciplinary and difficult to define which is why many prefer to describe what may fall under hybrid warfare without setting boundaries. True, the ingredients of hybrid warfare (e. g. military and nonmilitary, kinetic and non-kinetic, cyber, information operations and proxies) have been employed for some time. However, the innovation lies in the fact that a skillful combination of these ingredients can created unexpected successes and can serve as force multipliers. One especially interesting aspect of hybrid warfare is the use of law as a method of warfare. International legal order contains inevitably weaknesses and complexities, which can become tools of hybrid warfare. If a state knows the limits of the applicable legal framework, it can adjust its conduct in a way that a law-biding opponent is rendered defenseless or robbed of meaningful responses. Law is a readily available and often affordable methods that we should not underestimate.

48 International Committee of the Red Cross, Commentary on the First Geneva Convention, paragraph 236. 


\section{Bibliography}

Bartles, Charles K. "Getting Gerasimov Right.” Military Review (January-February 2016): $30-38$.

Brownlie, Ian. International Law and the Use of Force by States. Oxford: Clarendon Press, 1963.

Burke, John J. A. "Economic Sanctions against the Russian Federation Are Illegal under Public International Law." Russian Law Journal 3 (2015): 126-41.

Charap, Samuel. "The Ghost of Hybrid War." Survival 57, no. 6 (2017): 51-58.

Charter of the United Nations, San Francisco, June 26, 1945, entry into force October 24, 1945, 1 UNTS xvi.

Dinstein, Yoram. War, Aggression and Self-Defence. $5^{\text {th }}$ edn, Cambridge University Press, 2011.

European Commission. Joint Framework on Countering Hybrid Threats: A European Union Response. April 6, 2016. JOIN (2016) 18 final.

Geneva Convention for the Amelioration of the Condition of the Wounded and Sick in Armed Forces in the Field, August 12, 1949, entry into force October 21, 1950, 75 UNTS 31 .

Geneva Convention for the Amelioration of the Condition of Wounded, Sick and Shipwrecked Members of Armed Forces at Sea, August 12, 1949, entry into force October 21, 1950, 75 UNTS 85 .

Geneva Convention Relative to the Treatment of Prisoners of War, August 12, 1949, entry into force October 21, 1950, 75 UNTS 135.

Geneva Convention Relative to the Protection of Civilian Persons in Time of War, August 12, 1949, entry into force October 21, 1950, 75 UNTS 287.

Gerasimov, Valerij. "Cennost nauki v predvidenii: Novye vyzovy trebuyut pereosmyslit formy i sposoby vedeniya boevyh dejstvij [The Validity of Science is in Prediction: New Challenges Require Rethinking of Forms and Methods of Armed Activities Conduction]." Voenno-promyshlennyj kurer, 27 fevralya 2013. Accessed March 31, 2020. http://www.vpk-news.ru/articles/14632.

Halper, Stefan. "China: The Three Warfares." Report to the Office of the Secretary of Defense (May 2013).

Hoffman, Frank G. Conflict in the 21st Century: The Rise of Hybrid Warfare. Arlington: Potomac Institute for Policy Studies, 2007.

Hoffman, Frank G. "On Not-So-New Warfare: Political Warfare vs Hybrid Threats." War on the Rocks, July 28, 2014. Accessed March 31, 2020. https://warontherocks. com/2014/o7/on-not-so-new-warfare-political-warfare-vs-hybrid-threats/.

International Committee of the Red Cross. Commentary on the First Geneva Convention: Convention (I) for the Amelioration of the Condition of the Wounded and Sick in Armed Forces in the Field. $2^{\text {nd }}$ edn, Cambridge: Cambridge University Press, 2016.

International Court of Justice. Military and Paramilitary Activities in and against Nicaragua (Nicaragua v. United States). Merits. ICJ Reports (1986) 14.

International Court of Justice. Legal Consequences of the Construction of a Wall in the Occupied Palestinian Territory. Advisory Opinion. ICJ Reports (2004) 136. 
International Court of Justice. Legality of the Threat or Use of Nuclear Weapons. Advisory Opinion. ICJ Reports (1996) 226.

International Criminal Tribunal for the former Yugoslavia. Prosecutor v. Tadić. Case No. IT-94-1-I. Decision on Defence Motion for Interlocutory Appeal on Jurisdiction.

Kofman, Michael, and Matthew Rojansky. "A Closer look at Russia's "Hybrid War"." Kennan Cable, no. 7 (2015).

MacAskill, Ewen, "Russian troops removing ID markings 'gross violation." The Guardian, March 6, 2014. Accessed March 31, 2020. https://www.theguardian.com/news/ defence-and-security-blog/2014/mar/o6/ukraine-gross-violation-russian-troops.

Mattis, James N., and Frank G. Hoffman. "Future Warfare: The Rise of Hybrid Wars." Proceedings Magazine 131 (2005): 18-19.

Ministerstvo inostrannyh del Rossijskoj Federacii. "Pravovye obosnovaniya pozicii Rossii po Krymu i Ukraine [Legal Grounds of Russia's Position on Crimea and Ukraine]." 27 oktyabrya 2014. Accessed March 31, 2020. http://russische-botschaft. ru/wp-content/uploads/2014/10/Krym-pravovye-osnovy.doc.

Monaghan, Andrew. “The 'War' in Russia's 'Hybrid Warfare'. Parameters 45, no. 4 (2015): 65-74.

North Atlantic Treaty, Washington, April 4, 1949, entry into force August 24, 1949, 34 UNTS 243.

North Atlantic Treaty Organization, Allied Joint Doctrine, AJP-o1, Edition E Version 1 (February 2017).

North Atlantic Treaty Organization. "Brussels Summit Declaration." July 11, 2018. Accessed March 31, 2020. https://www.nato.int/cps/en/natohq/official_texts_133169.htm.

North Atlantic Treaty Organization. "Statement by the North Atlantic Council." September 12, 2001. Accessed March 31, 2020. https://www.nato.int/docu/pr/2001/ po1-124e.htm.

North Atlantic Treaty Organization. "Wales Summit Declaration." September 5, 2014. Accessed March 31, 2020. http://www.nato.int/cps/en/natohq/official_ texts_112964.htm.

North Atlantic Treaty Organization. "Warsaw Summit Declaration." July 9, 2016. Accessed March 31, 2020. https://www.nato.int/cps/en/natohq/official_texts_133169.htm.

Lee, Sangkuk. “China's 'Three Warfares': Origins, Applications, and Organizations.” Journal of Strategic Studies 37 (2014): 198-221.

Protocol Additional (I) to the Geneva Conventions, relating to the Protection of Victims of International Armed Conflicts, June 8, 1977, entry into force December 7, 1978, 1125 UNTS 3 .

Protocol Additional (II) to the Geneva Conventions, relating to the Protection of Victims of Non-International Armed Conflicts, June 8, 1977, entry into force December 7 , 1978, 1125 UNTS 6og.

Putin, Vladimir. "Address by President of the Russian Federation." Accessed March 31, 2020. http://en.kremlin.ru/events/president/news/206o3.

Putin, Vladimir. "Direct Line with Vladimir Putin." Accessed March 31, 2020. http:// en.kremlin.ru/events/president/news/20796. 
Rácz, András. "Hybrid War in Ukraine: Breaking the Enemy's Ability to Resist." Finnish Institute of International Affairs Report 43 (2015).

Reeves, Shane R., and Robert E. Barnsby. "The New Griffin of War: Hybrid International Armed Conflicts." Harvard International Review 34, no. 3 (2013): 16-18.

Riva, Alberto. "Russia's Use of Unmarked Troops in Simferopol, Crimea: Shady, But Not Illegal." International Business Times, March 4, 2014. Accessed March 31, $202 \mathrm{O}$. https://www.ibtimes.com/russias-use-unmarked-troops-simferopol-crimeashady-not-illegal-1559425.

Ruys, Tom. "Armed attack" and Article 51 of the UN Charter: Evolutions in Customary Law and Practice. Cambridge: Cambridge University Press, 2010.

Schrijver, Nico. "The Ban on the Use of Force in the UN Charter." In The Oxford Handbook of the Use of Force in International Law, edited by Marc Weller, 465-87. Oxford: Oxford University Press, 2015.

Schwarzenberger, Georg. "Jus Pacis Ac Belli? Prolegomena to a Sociology of International Law." American Journal of International Law 37 (1943): 46o-79.

Topychkanov, Petr. “'Hybrid War" — a Scholarly Term or a Propaganda Cliché?" Carnegie Endowment for International Peace, July 17, 2015. Accessed March 31, 202O. https:// carnegieendowment.org/2015/o7/17/hybrid-war-scholarly-term-or-propaganda-clich\%C3\%Ag.

Treaty Providing for the Renunciation of War as an Instrument of National Policy, Paris, August 27, 1928, entry into force July 24, 1929, 94 LNTS 57

United Kingdom Government, "Defence Secretary's speech to RUSI on the SDSR 2015." September 22, 2015. Accessed March 31, 2020. https://www.gov.uk/government/ speeches/defence-secretarys-speech-to-rusi-on-the-sdsr-2015.

United States Army Doctrine Reference Publication 3-o, Operations, October 6, 2017. Vité, Sylvain. "Typology of Armed Conflicts in International Humanitarian Law: Legal Concepts and Actual Situations." International Review of the Red Cross 91, no. 873 (2009).

Värk, René. "Declared and Undeclared Wars." Journal on Baltic Security 3, no. 1 (2017): 25-31.

Wittes, Benjamin. "What Is Hybrid Conflict?" Lawfare, September 11, 2015. Accessed March 31, 2020. https://www.lawfareblog.com/what-hybrid-conflict.

René Värk is an Associate Professor of International Law at the School of Law, University of Tartu, Estonia

Acknowledgements: The research and writing of the article were supported by the grant PRGg69 from the Estonian Research Council. 


\title{
Юридичні Складнощі Здійснення Гібридних Військових Дій
}

\author{
Рене Верк \\ професор \\ Університет Тарту, Естонія
}

\begin{abstract}
Анотація
Гібридні військові дії стосуються використання військових та невійськових засобів нелінійним та нестандартним способом. Різноманітні засоби та способи не є обов'язково ефективними, якщо застосовуються поодинці, однак, їх синергія може спричинити бажаний результат. Право також стало одним із засобів гібридних військових дій. Держави цілеспрямовано експлуатують юридичні складнощі для того, щоб зміцнити свої власні позиції та послабити позиції їх опонентів. Вони можуть вважати за доцільне підтримувати інтенсивність здійснення таких дій настільки, наскільки це можливо, щоб не перетнути межу, за якою можливе використання сили або погроза такого використання, для того, щоб мати можливість заявляти, що міжнародне право не було порушене і що опоненти не можуть звертатися до аргументів про самооборону. Держави можуть уникати необхідності застосування права, що регулює військові дії, зазначаючи, що ситуація ще не перетнула межі, коли ії можна визнати збройним конфліктом. Оскільки чинне правове регулювання військових дій писалося під традиційні бойові дії, численні колізії, прогалини та грані, які проводять ці правила, надають численні можливості для можливих маніпуляцій в ері сучасних бойових дій.
\end{abstract}

Ключові слова: гібридні військові дії, маніпуляція правом, правила військових дій, використання сили, Росія, Україна 